\title{
Light and electron microscopic study on the effect of immobilization stress on adrenal cortex of adult rats and possible ameliorative role of vitamin $\mathbf{E}$.
}

\author{
Original \\ Zainab M. Altayeb ${ }^{1}$ and Maysara M. Salem ${ }^{2}$ \\ Article \\ ${ }^{1}$ Histology and Cell Biology Department, Faculty of Medicine, Helwan University \\ ${ }^{2}$ Histology and Cell Biology Department, Faculty of Medicine, Benha University
}

\begin{abstract}
Background: Modern society is full of stress. Immobilization stress is a model used in animals to study its effects. Vitamin E is an antioxidant that protects biological membranes from oxidative stress.

Objectives: This study aimed to investigate the effects of immobilization stress on the adrenal cortex of rats and the ameliorative effect of vitamin E.

Materials and Methods: Forty adult male rats were used in this study and were divided equally into 4 groups. Group I: were divided equally into negative and positive controls. Group II: rats received vitamin E at a dose of 40 I.U/ $\mathrm{kg}$ by gastric tube for 30 days. Group III: rats subjected to immobilization stress 2 hours /day for 30 days. Group IV: rats subjected to immobilization stress 2 hours /day and received 40 I.U/kg of vitamin E for 30 days. Adrenal sections were histologically prepared and examined.

Results: Group II was comparable to group IA. Group III revealed zona glomerulosa (ZG) with loss of normal architecture, zona fasciculata (ZF) with multiple cells containing cytoplasmic vacuolations and darkly stained nuclei. By EM ZG cells appeared with accumulations of lipid droplets and lysosomes, irregular nuclear envelopes and chromatin condensation. ZF cells showed numerous lipid droplets and irregular nuclear envelopes. There were significant increases in the mean area of collagen fibers and mean serum cortisol level. Group IV revealed regression of these changes and increase in the mean count of CD44 +ve cells.
\end{abstract}

Conclusions: Immobilization stress exerted deleterious suprarenal cortical changes and vitamin $\mathrm{E}$ had an ameliorative effect.

Key Words: Adrenal cortex, immobilization stress, suprarenal gland, vitamin E.

Revised: 18 April 2017, Accepted: 3 May 2017

Corresponding Author: Maysara Mahmoud Salem, Tel.: 0403303514, E-mail: maysara.m.salem@gmail.com

ISSN:2536-9172, June 2017, Vol. 1, No. 1

\section{INTRODUCTION}

Stress has become an increasingly discussed topic nowadays in the world. This topic is discussed extensively in the health care fields, economics, finance, political science, education and business. The physiologic response to stress is involved as a contributor to a variety of individual physical and mental challenges and societal problems. Current stressors for examples include economy, paying bills, maintaining health care and keeping a job ${ }^{[1]}$. The term stress as used in biology has been defined as any change in the environment that changes an existing optimal steady state. Most of these stresses activate processes at the molecular, cellular, or systemic level that help to restore the previous state, that is to say, they are homeostatic reactions. Some of the stresses stimulate ACTH secretion. The rise in adrenocorticotropic hormone (ACTH) secretion is essential for survival when the stress is severe ${ }^{[2]}$.
In such condition, it is important to maintain blood pressure, to provide extra energy sources in the blood, and to temporarily shut down non essential functions. Cortisol is the most important hormone that carries out these activities $^{[3]}$. Immobilization stress has been commonly used as acute and chronic stress inducer in rats ${ }^{[4-6]}$. Under immobilization stress, the histological changes were elucidated in mammary glands ${ }^{[7]}$ and colonic mucosa ${ }^{[8]}$. Gabry et al. ${ }^{[9]}$ also demonstrated many histological changes in the gastric mucosa of rats under immobilization stress for different durations.

El-Refaiy ${ }^{[10]}$ stated that the immobilization stress of rats for 2 hours daily for different durations caused marked reduction of spermatogenesis, degeneration of germinal epithelium, thickening of basement membrane, haemorrhage and marked rise of collagen fibres. Mazroa and Asker $^{[1]}$ found ultrastructural changes in zona 
fasciculata cells of rat adrenal cortex after exposure to high temperature stress.

Vitamin E is a natural major lipid soluble antioxidant that is known to protect biological membranes and lipoproteins from oxidative stress ${ }^{[12]}$. The main biological function of vitamin $\mathrm{E}$ is its direct influence on cellular responses to oxidative stress through modulation of signal transduction pathways ${ }^{[13]}$. One of the protective roles of vitamin $\mathrm{E}$ is prevention of lipid peroxidation and inhibition of superoxide dismutase and catalase activities in liver ${ }^{[14]}$.

\section{AIM OF THE WORK}

Therefore, this study aimed to investigate the effect of immobilization stress on adrenal cortex of adult rats and possible ameliorative role of vitamin E using light, ultrastructural, morphometric and serological studies.

\section{MATERIALS AND METHODS}

\section{Drug:}

Vitamin E capsules were obtained from Pharco Pharmaceuticals, Alexandria, Egypt. Each capsule contains 400 international units (I.U).

\section{Animals:}

The present study was carried out on 40 normal adult male albino rats, aged $3-4$ months and their body weight ranged between 190 and 210 gms. They were obtained from the Animal House of Moshtohor Faculty of Veterinary Medicine, Benha University and acclimatized to the laboratory conditions. They were housed in plastic cages with mesh wire covers under the prevailing atmospheric conditions and were given food and water ad libitum. The rats were sacrificed according to the Ethics Committee Recommendations of Benha University.

The animals were randomly divided into 4 groups, each group contained ten rats:

Group I (Control group): 10 rats were divided into two subgroups each containing five animals:

Subgroup IA: kept as a negative control, they were left without intervention.

Subgroup IB: kept as a positive control each animal was given $0.5 \mathrm{ml}$ of corn oil (the vehicle of vitamin $\mathrm{E}$ ) once daily by gastric tube for 30 consecutive days.

Group II: rats received vitamin E at a dose of 40 I.U/ $\mathrm{kg}$ body weight dissolved in $0.5 \mathrm{ml}$ corn oil once daily by gastric tube for 30 consecutive days.
Group III: rats subjected to immobilization stress 2 hours /day at 10 a.m. -12 p.m. for 30 consecutive days.

Group IV: rats subjected to immobilization stress 2 hours /day at 10 a.m. -12 p.m. and received 40 I.U/kg body weight of vitamin $\mathrm{E}$ dissolved in $0.5 \mathrm{ml}$ corn oil once daily by gastric tube for 30 consecutive days. Twenty four hours after the end of experiment, animals in all groups were sacrificed by cervical dislocation under anaesthesia ${ }^{[15]}$, then dissected and blood samples were obtained from the left ventricle by canula.

\section{Immobilization stress:}

Rats were exposed to stress for 2 hours daily between 10:00 a.m. to $12: 00$ p.m. The animals were individually placed in wire stainless mesh restrainers $(5 \times 7 \times 12 \mathrm{~cm}$ in dimensions) as described by Soliman ${ }^{[7]}$. This procedure effectively restricted movement of the animals. Control group were housed in normal stainless cages $(20 \times 35 \times$ 60) $\mathrm{cm}^{[6]}$

\section{A- Light microscopic study:}

The specimens of each animal were collected from right gland and divided in the sagittal plane into two halves. The first halves were fixed in $10 \%$ formal saline, dehydrated, cleared and embedded in paraffin wax. Sections of 5 $\mu \mathrm{m}$ thick were cut and stained with haematoxylin and eosin (H\&E) to verify histological details and Masson's trichrome to assess collagen fibers ${ }^{[16]}$.

\section{Immunohistochemical study:}

CD44 immunostaining: primary (1ry) antibody (Ab) was used to detect the endogenous mesenchymal stem cells (MSCs) ${ }^{(17)} .7 \mathrm{ml}$ prediluted rabbit monoclonal 1ry $\mathrm{Ab}$ (IW-PA1021) (IHC World, Ellicott City, USA) stored at $2 \sim 8^{\circ} \mathrm{C}$. The 1ry $\mathrm{Ab}$ was applied to the sections, incubation took place in humidity chamber for 60 minutes at room temperature. The +ve tissue control was a specimen of human tonsil. CD44 +ve cells showed membranous reaction. The - ve tissue control was processed in the same way, but omitting the step of 1ry Ab.

\section{B- Electron microscopic study:}

The second halves of right adrenal glands were prepared for electron microscopic (EM) examination as follow: Four to five small pieces were taken from the right gland of each rat and were fixed in glutaraldehyde and osmium tetroxide. The fixed parts were dehydrated and embedded in Epon 812. Semithin sections, $1 \mu \mathrm{m}$ thick were cut and stained with toluidine blue and examined by LM to choose the selected areas for proper orientation. Ultrathin sections were stained by uranyl acetate and lead citrate ${ }^{[18]}$. The EM study was performed with a Jeol 1010 Transmission 
Electron Microscope (Japan) at the Regional Center for Mycology and Biotechnology, Al-Azhar University.

\section{C-Morphometric study:}

The morphometric study was done by using computer assisted image analysis using Olympus camera connected to Olympus microscope. The area $\left(\mu^{2}\right)$ of darkly stained nuclei, that of cytoplasmic vacuolations and of collagen fibers, in addition to the count of CD44 +ve cells were measured. The measurements were done in 10 high power fields using interactive measurements menu.

\section{D-Serological study:}

The blood collected from the left ventricle of each rat was placed in tubes and the serum was obtained and frozen for measuring the level of cortisol. Serum cortisol was determined using a radioimmunoassay kit (Biochemicals, Costa Mesa, CA, USA) and the values expressed as ng cortisol / $\mathrm{ml}$ serum.

\section{Statistical analysis ${ }^{[19]}$ :}

Statistical evaluation of the morphometric results was performed by using SPSS software (version 20; SPSS Inc., Chicago, Illinois, USA). Values were expressed as means \pm SD and compared using one way analysis of variance (ANOVA). For hormonal results, differences were assessed using Student's t-test. Values of $\mathrm{P}<0.05$ were considered statistically significant.

\section{RESULTS}

\section{Group I:}

\section{LM results:}

H\&E examination: revealed the normal architecture of suprarenal gland which is surrounded by a thin capsule formed of fibrous connective tissue, a cortex showing the normal zonation formed of outer most zona glumerulosa $(\mathrm{ZG})$, middle zona fasciculata $(\mathrm{ZF})$ and inner most zona reticularis (ZR). The medulla is present in the center of the gland (Fig. 1-A). The ZG is formed of clusters of rounded or arched groups of columnar cells with stainable cytoplasm. The ZF which is formed of polyhedral vacuolated cells with acidophilic cytoplasm form radial cords one or two cells thick, perpendicular to the capsule of the gland and directed to the center, separated by fine trabeculae contain multiple blood capillaries. The cells of the ZF have a lightly staining spherical nucleus (Fig. 1-B). The ZR cells are small, closely packed and deeply stained polyhedral cells arranged in irregular network of intermingled cords separated by blood sinusoids. The adrenal medulla consists of closely packed cells arranged in irregular clusters of secretory chromaffin cells (Fig. 1-C).

Masson's trichrome stain: showed fine collagen fibers throughout the suprarenal cortex (Fig. 2-A).

Immunohistochemical reaction for CD44: demonstrated negative immunoexpression (Fig. 2-B).

EM results: showed $\mathrm{ZG}$ cells with abundant lipid droplets, oval nuclei surrounded by nuclear envelopes, having prominent nucleoli. The nuclei had abundant euchromatin and few heterochromatin (Fig. 3-A). ZF cells showed lipid droplets, nuclei surrounded by nuclear envelopes, having large amount of euchromatin and few heterochromatin (Fig. 3-B). The ZR cells illustrated lipid droplets, lysosomes, and round to oval nuclei possessing euchromatin and peripheral heterochromatin (Fig. 3-C).

Group II: H\&E, Masson's trichrome, immunohistochemical and electron microscopic results of this group were comparable to the control group.

\section{Group III:}

\section{LM results:}

H\&E examination: revealed $\mathrm{ZG}$ with loss of normal architecture, obviously vacuolated cells and multiple darkly stained nuclei. ZF showed obviously vacuolated cells and multiple darkly stained nuclei. Other cells exhibited dark acidophilic cytoplasm and darkly stained nuclei (Fig. 4-A and 4-B) in addition to multiple congested blood capillaries and vessels (Fig. 4-C). ZR showed cells with multiple dark nuclei and adrenal medulla chromaffin cells (Fig. 4-D).

Masson's trichrome stain: showed an apparent increase of collagen fibers among the cortex that were seen dense (Fig. 5-A).

Immunohisochemical reaction for CD44: showed few CD44 +ve cells among the cortex of the gland (Fig. 5-B).

EM results: showed ZG cells with accumulations of lipid droplets, nuclei with indented nuclear envelope and bodies with electron dense and electron lucent areas and irregular outlines (Fig. 6-A). Lysosomes, some nuclei with chromatin condensation and irregular shape were seen (Fig. 6-B). ZF cells showed numerous lipid droplets with irregular outlines and lysosomes. Some nuclei appeared with indentation of their nuclear envelopes (Fig. 7-A). Cells of ZF appeared with multiple lysosomes and mitochondria (Fig. 7-B). ZR cells showed 
accumulation of lipid droplets of variable sizes, nuclei with nuclear envelope indentation, heterogeneous bodies surrounded by clear areas, lysosomes and mitochondria (Fig. 7-C).

\section{Group IV:}

\section{LM results:}

H\&E examination: revealed ZG with few obviously vacuolated cells, $Z F$ with fine trabeculae and some obviously vacuolated cells, in addition to few darkly stained nuclei and less congested capillaries (Fig. 8-A). ZR appeared with multiple congested blood sinusoids and apparent normal cells (Fig. 8-B).

Masson's trichrome stain: showed fine collagen fibers among the cortex (Fig. 9-A).

Immunohisotchemical reaction for CD44: showed multiple CD44 +ve cells near blood vessels, among the cortex, at the capsule and in the adjacent adipose tissue (Fig. 9-B and 9-C).

EM results: showed ZG cell had spherical nuclei surrounded by nuclear envelope with marginated heterochromatin, euchromatin, and lipid droplets (Fig. 10-A). ZF cells showed multiple accumulations of some lipid droplets with irregular shapes, mitochondria few lysosomes and euchromatic nuclei (Fig. 10-B). ZR cells showed multiple lipid droplets, euchromatic nuclei, prominent nucleolus and bodies with electron dense and electron lucent areas and irregular outlines (Fig. 10-C).

\section{C) Morphometric results:}

A significant increase was found in the mean areas of darkly stained nuclei, that of cytoplasmic vacuolations and that of collagen fibers in group III compared to the other groups. In addion, a significant increase in the mean area of cytoplasmic vacuolations was found in group IV compared to groups I and II.

Concerning mean count of CD44 +ve cells a significant increase was detected in group IV compared to group III (Table 1).

\section{D) Serological results:}

Animals of group III showed a highly significant increase in mean serum level of cortisol as compared to negative control rats.

Animals of group IV showed significant increase in mean serum level of cortisol as compared to negative control rats $(p<0.05)$ and significant decrease compared to group III (Table 2 and Histogram 1).

Table 1: Mean \pm SD area of darkly stained nuclei, area of cytoplasmic vacuolations and area of collagen fibers and count of CD $44+\mathrm{ve}$ cells:

\begin{tabular}{ccccc}
\hline & Mean area of darkly & Mean area of & Mean area of & Mean count of \\
stained nuclei & cytoplasmic vacuolations & collagen fibers & CD44+ve cells
\end{tabular}

\begin{tabular}{|c|c|c|c|c|}
\hline GroupI & - & $2.9 \pm 0.5$ & $1.3 \pm 0.2$ & - \\
\hline GroupII & - & $3.4 \pm 0.7$ & $1.6 \pm 0.3$ & - \\
\hline GroupIII & $20.6 \pm 3.8^{*}$ & $29.3 \pm 3.9^{*}$ & $6.3 \pm 1.8^{*}$ & $3.3 \pm 0.6$ \\
\hline GroupIV & $6.4 \pm 0.9$ & $9.7 \pm 2.1 * *$ & $2.2 \pm 0.5$ & $8.2 \pm 2.1 *$ \\
\hline
\end{tabular}

*Significant increase compared to the other groups

** Significant increase compared to groups I and II 
Table 2: Mean of cortisol serum levels in all groups and their significances as compared to negative control subgroup

$\begin{array}{lrl}\text { Groups } & \text { (Cortisol level (ng/ml }\end{array}$

Negative

$\mathrm{X} \pm \mathrm{SD}$

$\mathrm{X} \pm \mathrm{SD}$

$\mathrm{P}$

Sig

$\mathrm{X} \pm \mathrm{SD}$

$\mathrm{P}$

Sig.

$\mathrm{X} \pm \mathrm{SD}$

Sig.

$\mathrm{X} \pm \mathrm{SD}$

P

Sig.
207. $2 \pm 13.4$

$215.1 \pm 10.6$

$>0.05$

Non significant.

$205.7 \pm 14.1$

$>0.05$

Non significant.

$397.3 \pm 37.5$

$<0.001$

Highly significant.

$279.5 \pm 41.7$

$<0.05$

Significant.

$X=$ Mean values.

$\mathrm{SD}=$ Standard Deviation.

Highly significant increase in group III.

Significant decrease $(p<0.05)$ between group IV in comparison with group III 


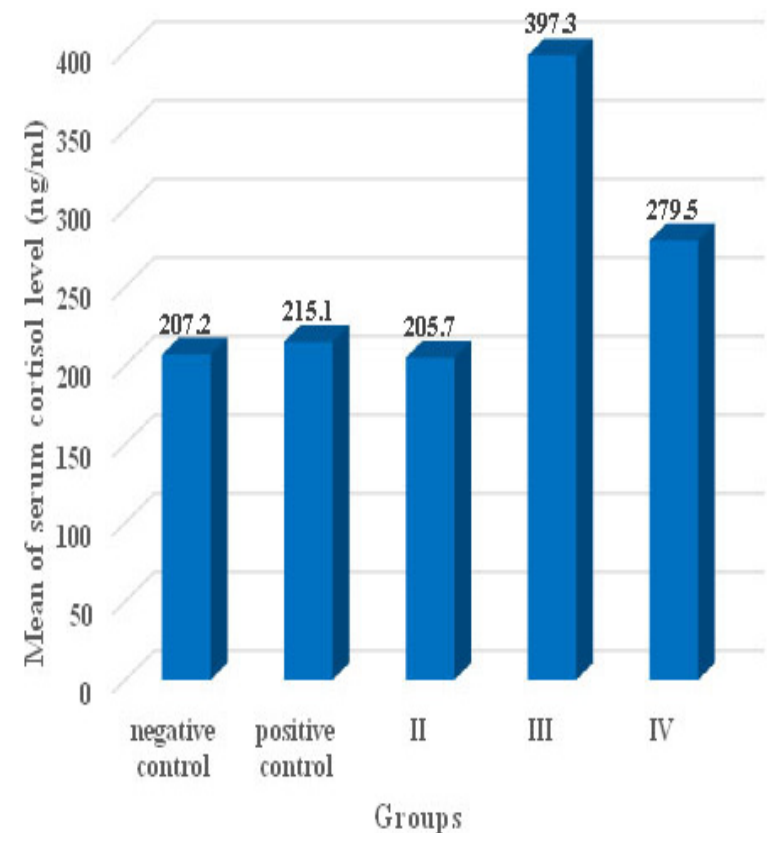

Histogram 1: showing means of serum cortisol levels ( $\mathrm{ng} / \mathrm{ml})$ in all groups
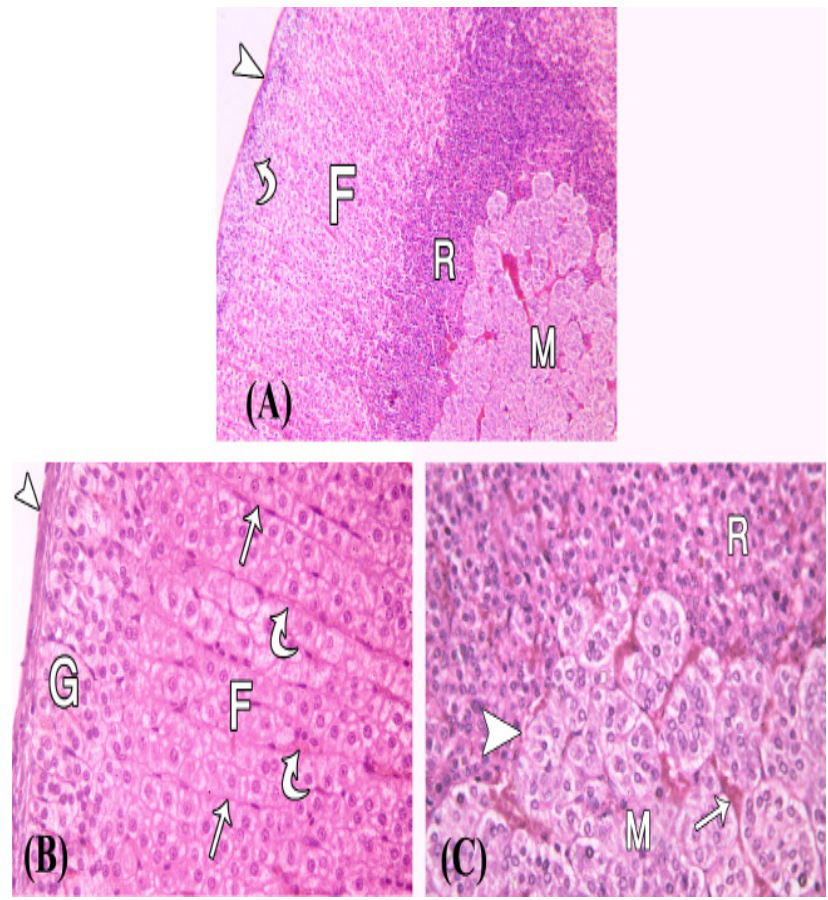

Fig. 1: Photomicrographs of sections in the rat adrenal gland (H\&E) from group I showing: A: the capsule (arrow head) with underlying ZG (bent arrow), parallel cell cords of ZF (F), ZR (R) and part of the medulla (M). (X 100). B: the capsule which is formed of connective tissue (arrow head), ZG cells $(\mathrm{G})$ is formed of arched group of cells with pale cytoplasm, ZF cells (F) which form radial cords of cells with vacuolated cytoplasm, separated by fine trabeculae $(\uparrow)$ contain multiple blood capillaries (bent arrows). (X 400). C: ZR (R) with small closely packed and deeply stained cells arranged in intermingled cords. The adrenal medulla (M) consists of closely packed chromaffin cells arranged in irregular clusters (arrow head) and blood sinusoids in between $(\uparrow)$

(X 400).
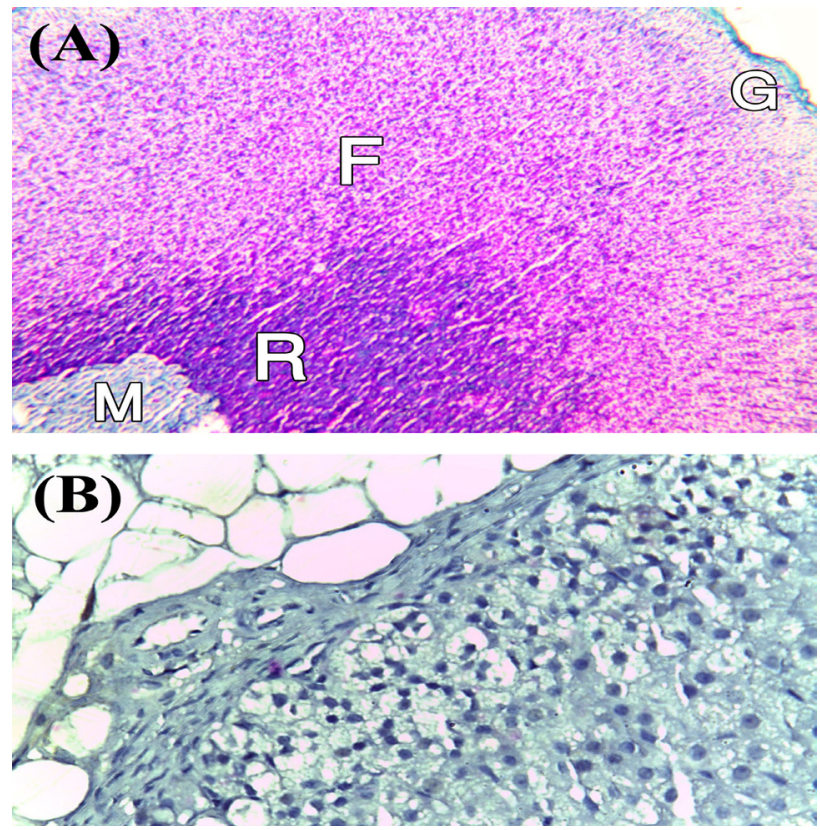

Fig. 2: Photomicrographs of sections in the adrenal gland of a rat from group I showing: A: demonstrating fine collagen fibers, ZG (G), ZF (F), ZR (R) and part of the medulla (M). (Masson's trichrome $\mathrm{X} 100)$. B: negative immunoexpression in the cortex. (CD44 immunostaining X 400)
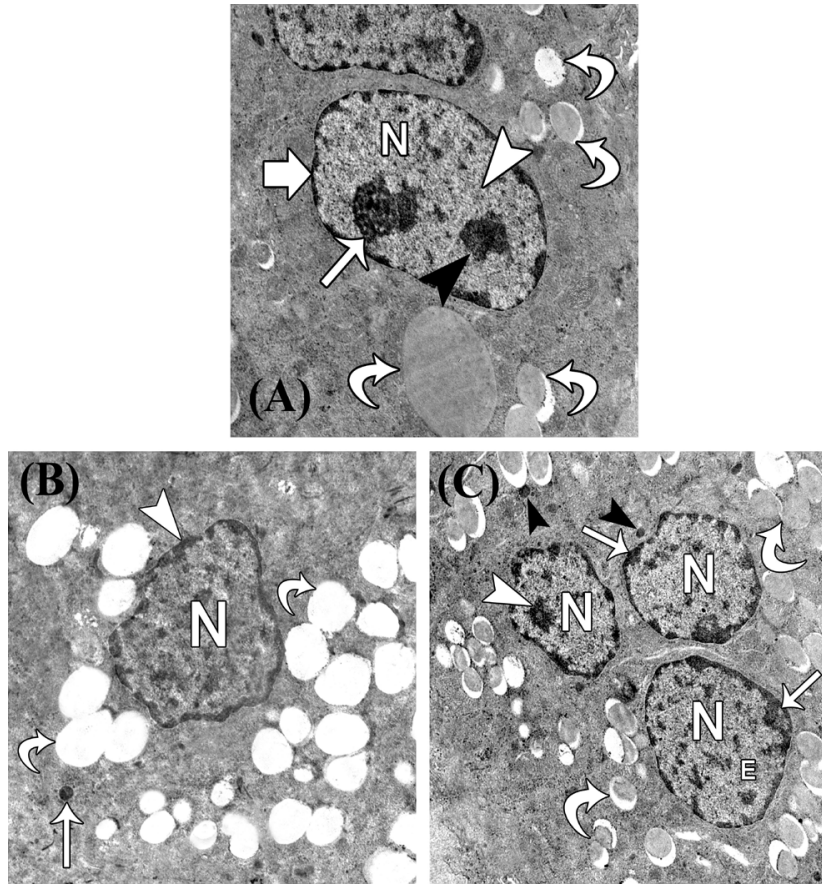

Fig. 3: Electron micrographs of group I showing: A: two neighboring cells in ZG with abundant lipid droplets (bent arrows), oval nuclei (N) surrounded by nuclear envelope (thick arrow), having prominent nucleolus $(\uparrow)$, heterochromatin (black arrow head) and euchromatin (white arrow head). (X 10000). $\mathrm{B}$ : a cell in ZF demonstrating multiple lipid droplets (bent arrows), nucleus $(\mathrm{N})$ surrounded by nuclear envelope (arrow head) and a lysosome $(\uparrow)$. (X 8000). C: ZR cells illustrating lipid droplets (bent arrows), lysosomes (black arrow heads) and round to oval nuclei $(\mathrm{N})$ possessing peripheral heterochromatin $(\uparrow)$, euchromatin (E) and nucleolus (white arrow head). $\quad$ (X 8000) 


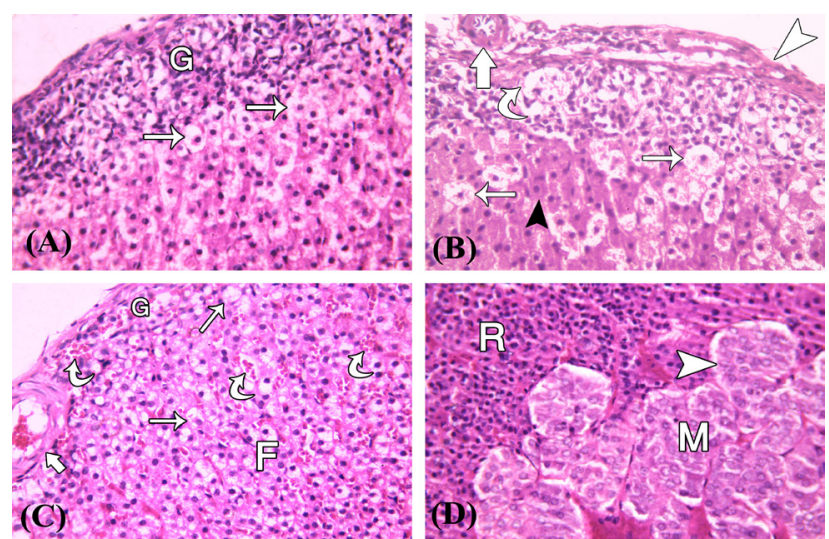

Fig. 4: Photomicrographs of sections in the rat adrenal gland from group III (H\&E X 400) showing: A: ZG (G) with loss of architecture and ZF cells showing obvious vacuolation and multiple darkly stained nuclei ( $\uparrow$ ). B: capsule (white arrow head), an artery (thick arrow), ZG with loss of architecture obviously vacuolated cells and darkly stained nuclei (bent arrow), ZF with some obviously vacuolated cells and darkly stained nuclei $(\uparrow)$. Other cells exhibit dark acidophilic cytoplasm and darkly stained nuclei (black arrow head). C: ZG (G) with loss of architecture and multiple congested blood capillaries (bent arrow), ZF with obviously vacuolated cells $(\uparrow)$ and congested blood capillaries (bent arrows). Note congested arteriole (thick arrow). D: ZR (R) cells with multiple dark nuclei $(\uparrow)$. Note adrenal medulla $(\mathrm{M})$ and chromaffin cells (arrow head).
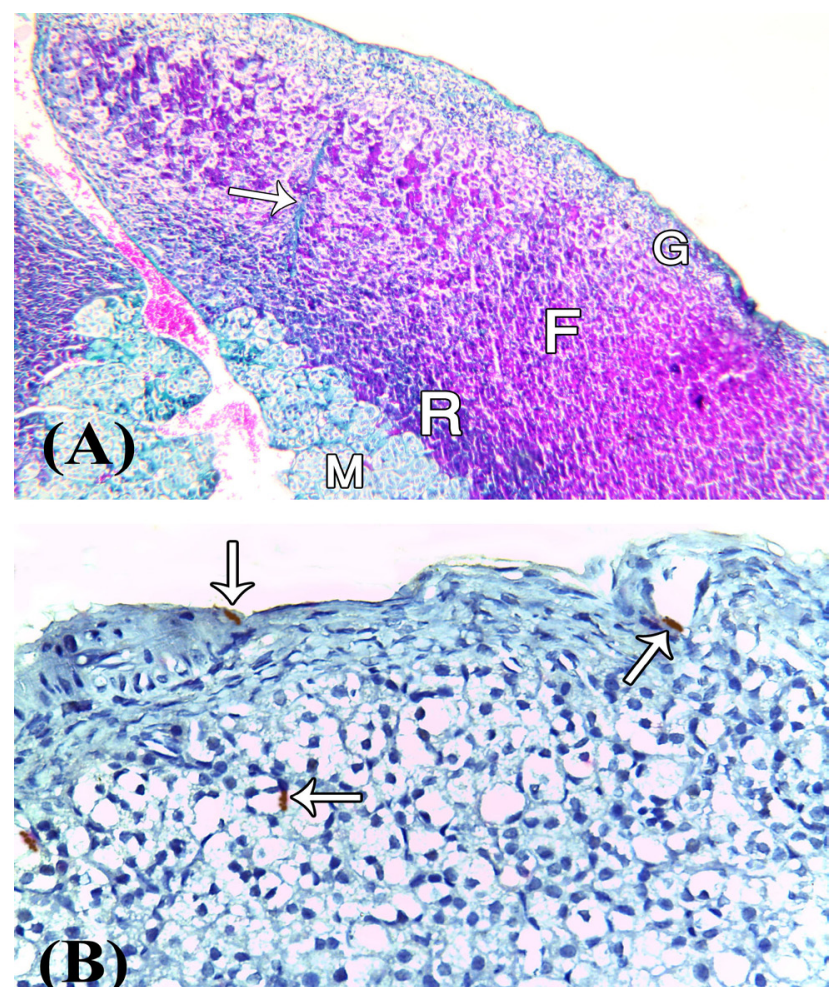

Fig. 5: Photomicrographs of sections in the rat adrenal gland from group III showing: A: ZG (G), ZF (F), ZR(R) and medulla (M) demonstrating dense collagen fibers $(\uparrow)$. (Masson's trichrome $\mathrm{X}$ 100). B: few +ve spindle cells at the capsule and in the cortex $(\uparrow)$.

(CD44 immunostaining, X 400)
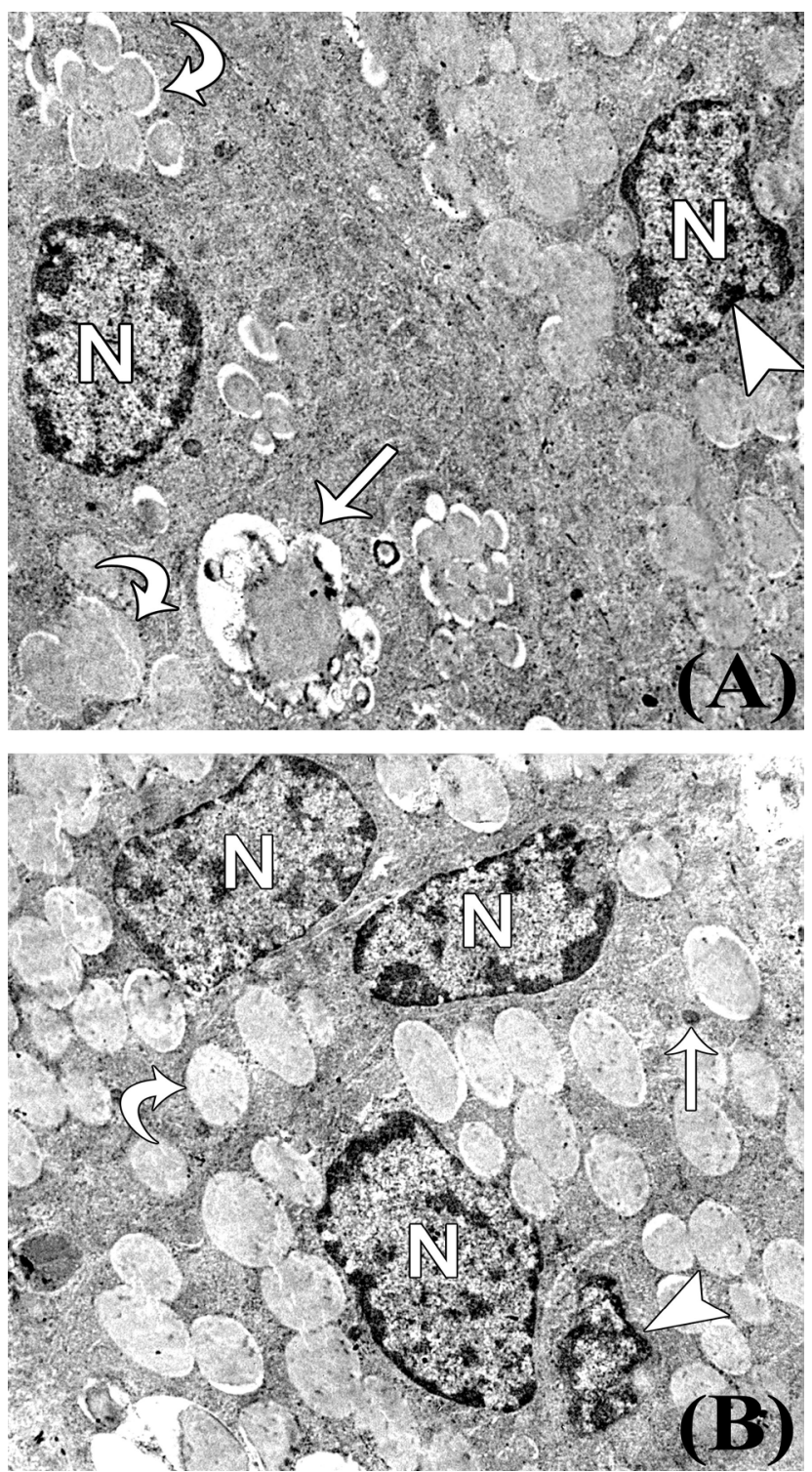

Fig. 6: Electron micrographs of group III (X 8000) showing: A: two adjacent cells in ZG in suprarenal cortex with accumulations of lipid droplets (bent arrows), a body with electron dense and electron lucent areas and irregular outline $(\uparrow)$. Two nuclei $(\mathrm{N})$ one of them with indented nuclear envelope (arrow head) were seen. B: ZG cells, one showing nuclear chromatin condensation and irregular shape (arrow head). Note the other apparently normal nuclei $(\mathrm{N})$, numerous accumulated lipid droplets (bent arrow) and lysosomes $(\uparrow)$. 

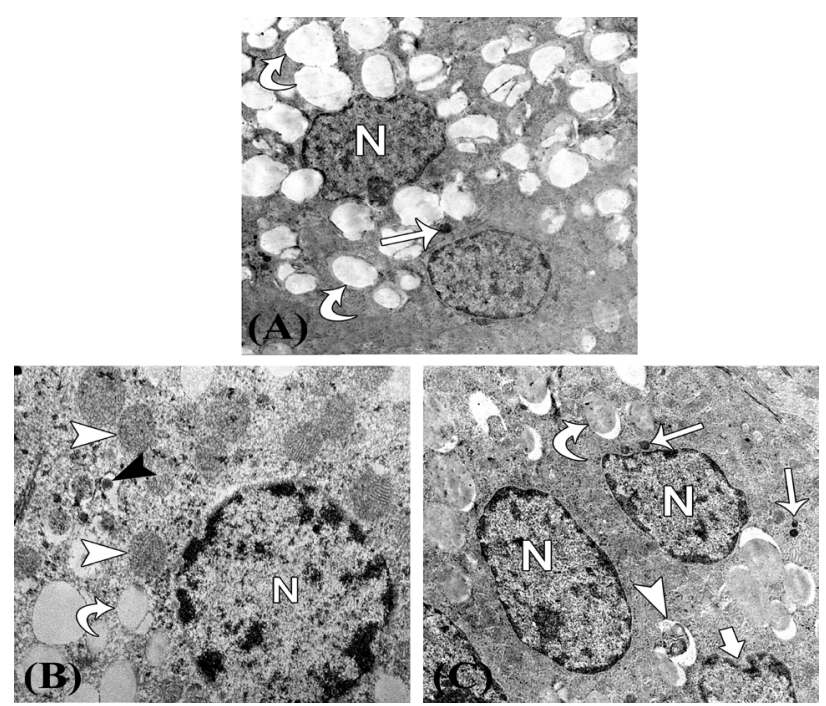

Fig. 7: Electron micrographs of group III showing: A: two adjacent cells in ZF loaded with numerous lipid droplets with irregular outlines (bent arrows), lysosomes $(\uparrow)$ and a nucleus (N) with indentation of its nuclear envelope. (X 8000). B: a cell in ZF illustrating multiple accumulated lipid droplets (bent arrow), mitochondria (arrow head), multiple lysosomes (black arrow head) and a nucleus (N). (X 25000). C: ZR cells with accumulation of lipid droplets of variable sizes (bent arrow), nuclei $(\mathrm{N})$, one with indentation of its nuclear envelope (thick arrow), heterogeneous body surrounded by a clear area (white arrow head) and multiple lysosomes $(\uparrow)$

(X 10000).
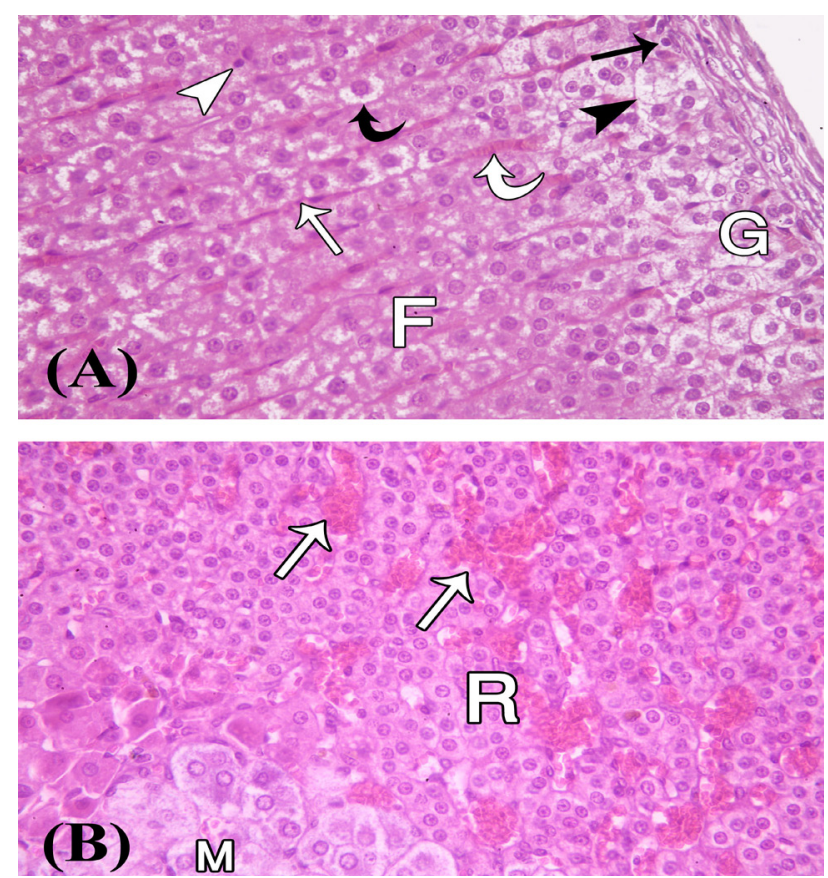

Fig. 8: Photomicrographs of sections in the rat adrenal gland from group IV (H\&E X 400) showing: A: ZG (G) with few obviously vacuolated cells (black arrow head) and few darkly stained nuclei (black $\uparrow$ ), ZF (F) with few darkly stained nuclei (white arrow head), some obviously vacuolated cells (black bent arrow), fine trabeculae (white $\uparrow$ ) and less congested capillaries (white bent arrow). B: ZR (R) with multiple congested sinusoids ( $\uparrow$ ) and apparently normal cells. Note adrenal medulla (M).

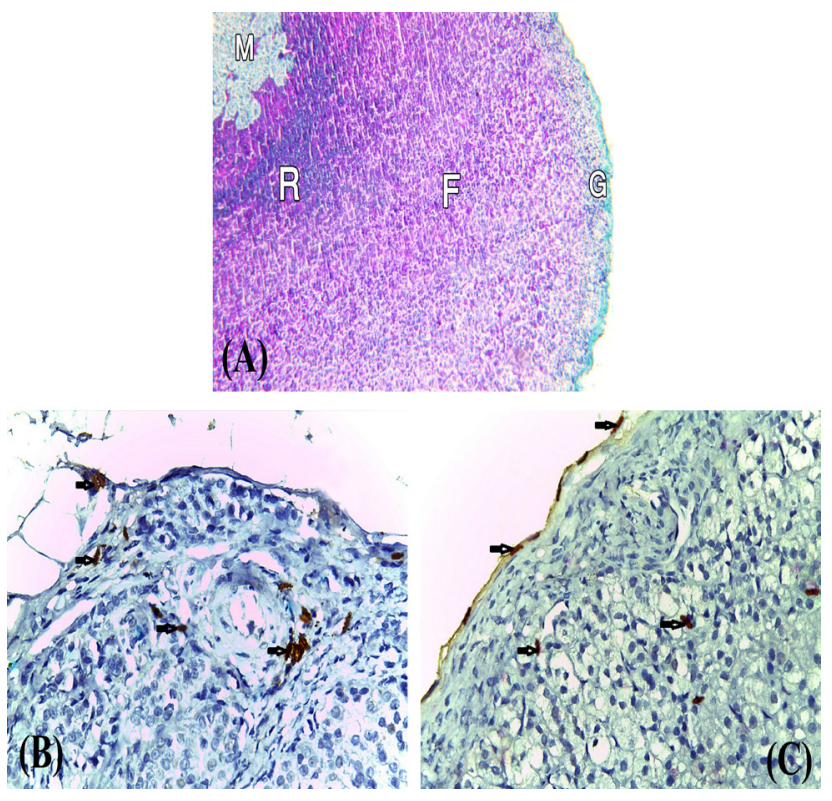

Fig. 9: Photomicrographs of sections in the rat adrenal gland from group IV showing: A: ZG (G), ZF (F), ZR (R) and part of the medulla (M) demonstrating fine collagen fibers.(Masson's trichrome X 100). B: multiple positive spindle cells ( $\uparrow$ ) near a blood vessel among the cortex and in the adjacent adipose tissue. (CD44 immunostaining X 400). C: multiple +ve spindle cells $(\uparrow)$ among the cortex and at the capsule.

(CD44 immunostaining X 400).
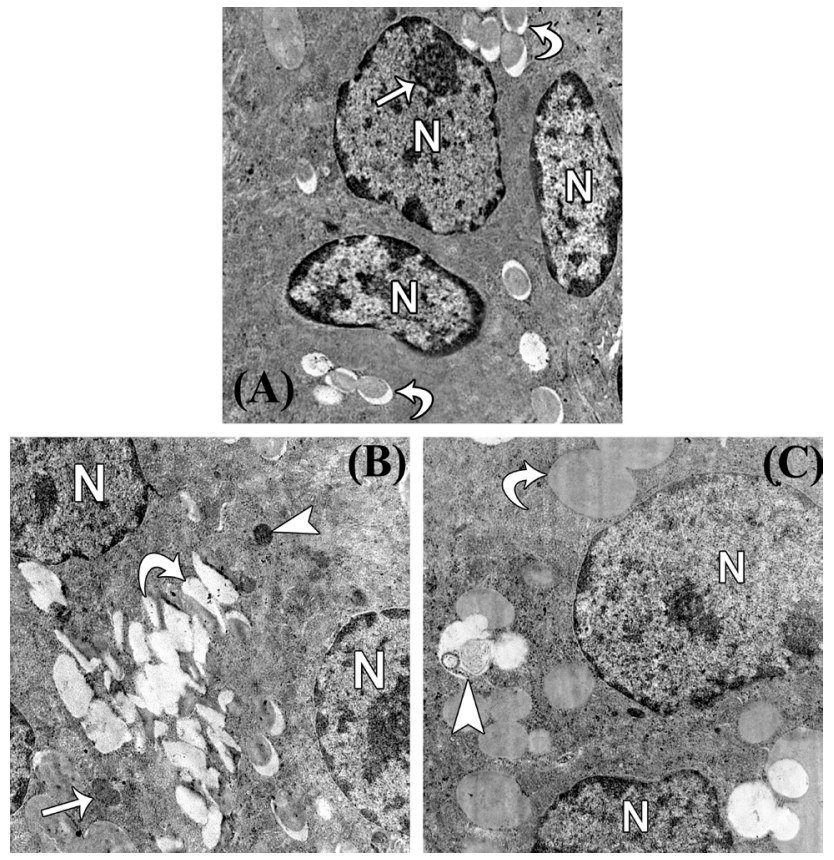

Fig. 10: Electron micrographs of group IV showing:A: cells of ZG having some lipid droplets (bent arrows), euchromatic nuclei (N) and nucleolus $(\uparrow)$. (X 8000). B: cells of ZF having accumulation of some lipid droplets with irregular shapes (bent arrow), mitochondria ( $\uparrow$ ) and few lysosomes (arrow head). Euchromatic nuclei $(\mathrm{N})$ are observed. (X 10000). C: two adjacent cells in ZR with multiple lipid droplets (bent arrow), euchromatic nuclei $(\mathrm{N})$ and a body with electron dense and electron lucent areas and irregular outline (arrow head).

(X 12000) 


\section{DISCUSSION}

Modern society is obviously full of stress. Stressful experiences include daily problems, major life events abuse, trauma, work-life balance, and many other events. When added to other stressors such as financial problems, the result may be potential suffering from the so called stress related disorders ${ }^{[20]}$

Therefore, this study was performed to evaluate the effect of immobilization stress on the adrenal cortex. The rats subjected to immobilization (group III) showed cells with obvious cytoplasmic vacuolations and darkly stained nuclei in ZF and ZG. The previous findings were confirmed by a significant increase in the mean area of darkly stained nuclei and cytoplasmic vacuolations in group III. These results can be referred to degenerative changes in the cortical cells. The previous results were confirmed by Liu et al. ${ }^{[21]}$ who reported that excessive oxidative stress alters the expression levels of apoptosis-related genes and triggers cell apoptosis and degeneration through bcl2 , bax and caspase-3 signaling pathways. This occurs in response to increased secretion of ACTH due to stress as this hormone stimulates both $\mathrm{ZF}$ and $\mathrm{ZR}$ to produce cortisol. Also, ACTH stimulates ZG, but to a lesser extent, to produce aldosterone hormone as the main stimulus for aldosterone secretion is angiotensin $\mathrm{II}^{[22]}$.

Hall ${ }^{[23]}$ stated that almost any type of physical or mental stress can lead to greatly enhanced secretion of ACTH and consequently cortisol as well. This effect was demonstrated by the strong adrenocortical secretory responses after trauma. Pain stimuli caused by physical stress or tissue damage are transmitted to the brain stem then to the hypothalamus. Corticotrophin releasing factor is secreted into the hypophysial portal system. This leads to large quantities of cortisol in the blood. Mental stress causes a rapid increase in $\mathrm{ACTH}$ secretion.

The adrenal cortical cells of rats in group III showed cytoplasmic vacuolization at light microscope and increase lipid droplets at EM level this is due to increase demand for lipids which form the corner stone for cortisol synthesis due to immobilization stress. This is in accordance with other investigators $^{[24]}$ who stated that long-lasting experimental hypodynamy results in increased number of lipid droplets in the cytoplasm of cortical cells that showed tendency to coalesce. Cholesterol, which accumulates in lipid globules as a reserve material is the principal precursor in the synthesis of steroid hormones. Accumulation of lipid globules may indicate a decreased transformation of cholesterol to corticosteroids.

However, other authors stated that the exposure to stress resulted in a significant exhaustion of lipid droplets in the adreno-corticocytes of all adreno-cortical zones, particularly in the ZF cells ${ }^{[25]}$.

In the present study some nuclear envelopes of adrenocortical cells showed irregularities and indentations these may not be pathological, simply may be due to compression of condensed lipid droplets on them. In accordance Pawlina ${ }^{[26]}$ stated that fat globule in late lipoblast compresses the nucleus and makes it flat and thin, moreover, it pushes the nucleus from its original central position to peripheral one.

The present study showed irregular nuclei with condensed chromatin and increased lysosomes that can be related to increased digestion of the accumulated lipids or the developing degeneration. These findings are in accordance with other investigators ${ }^{[27]}$ who found indented nuclei and occasional shrunken ones as well as increase lipid droplets in stressed animals.

The ZF cells of the rats of group III in the present study exhibited the presence of dark nuclei with highly acidophilic cytoplasm. Similar observations were reported by other researchers ${ }^{[27]}$ who stated that the stressed adrenal glands were characterized by the presence of plump of cells with greatly increased eosinophilia of the cytoplasm instead of the usual pale staining foamy cytoplasm of ZF cells. These changes correlate well with adrenocortical over stimulation and /or degeneration.

In the present study, the heterogeneous bodies with electron dense and electron lucent areas and irregular outlines revealed in ZG and ZR in group III are lipofusin bodies. Gilissen and Bobrovski ${ }^{[28]}$ stated that the important causal factor of lipofuscinogenesis involves free radicalinduced lipid peroxidation and oxidative enzymatic activity. A high rate of cellular activity may also cause an increased turnover of cellular products resulting in lipofuscin accumulation.

Many researchers ${ }^{[29]}$ stated that exposure to stress stimulates various pathways leading to increased production of free radicals that contribute to the occurrence of pathological conditions. Immobilization stress may also impair the antioxidant defense system, leading to oxidative damage, by disturbing the balance between oxidant and antioxidant factors.

In the present investigation, the adrenal cortex of III showed capillary and sinusoidal congestion. This congestion was attributed to an increase in ACTH, which stimulated the formation of prostaglandins leading to congestion ${ }^{[30]}$.

In the current study, collagen fibres increased in suprarenal cortex, confirmed by morphometry after exposure to stress. In agreement with the present results, many investigators found similar results. El-Refaiy ${ }^{[10]}$ found that fibroblasts and collagen fibers in stressed rats were increased and this leads to the thickening of testis basement membrane. Moreover, El-Drieny and Mousa ${ }^{[31]}$ reported that the colonic mucosa of rats exposed to stress showed features indicating fibrosis as a result of increased collagen synthesis by fibroblasts. 
El-Desouki et al ${ }^{[32]}$ reported that the immobilized stressed rats showed increment of collagen fibers in the adrenal cortex.

Rats in group IV revealed amelioration of these morphological changes and this is consistent with other authors ${ }^{[3-35]}$ who stated that vitamin E plays an important role in DNA repair, and other metabolic processes. Antioxidants such as vitamin $\mathrm{E}$ act to protect the cells against the effects of free radicals, which are the cause of oxidative damage to cell membranes.

Moreover Zhu et al. ${ }^{[36]}$ stated that vitamin E has several health benefits, such as antioxidant, anti-inflammatory and neuroprotective properties. In recent years, the use of vitamin E supplements as antioxidants has become common. Several studies have demonstrated that other micronutrients such as vitamin $\mathrm{E}$ and antioxidants play preventive roles in carcinogenesis.

The present study revealed presence of few CD44 +ve spindle cells at the capsule and among the cortex in group III and multiple cells among the cortex, at the capsule, near blood vessels and in the adjacent adipose tissue in group IV, confirmed by morphometry. It can be commented that sources of endogenous stem cells from the bone marrow or adipose tissue (which are rich in mesenchymal stem cells) reach the damaged organ through the circulation. The CD44 immunostaining is characteristic for mesenchymal stem cells. The presence of stem cells revealed in this study is in accordance with other investigators who discovered pools of stem/progenitor cells in the adrenal capsule, subcapsular and juxtamedullary regions that can differentiate to repopulate zones. They become activated only during specific developmental stages or in response to extreme physiological demand. Senescent cells can also be renewed through direct lineage conversion; for example, cells in the $\mathrm{ZG}$ can transform into cells of the $\mathrm{ZF}^{[37,38]}$.

Serum cortisol level in group III revealed highly significant increase as compared to negative control, this is in accordance with many investigators. Gesi et $a l{ }^{[39]}$ reported a marked increase of the cortisol levels in response to stressful stimuli such as noise or high ambient temperature that activated the hypothalamic pituitary adrenal axis leading to a release of ACTH. Similarly, other researchers ${ }^{[11,40]}$ stated that immobilization stress response-related disorders resulted in the hypersecretion of both ACTH and corticosterone to a subsequent stressor.

On the other hand serum cortisol level in group IV revealed significant decrease as compared to group III but still high as compared to negative control. This reflects the partial protective role of vitamin $\mathrm{E}$ that can be related to its antioxidant effect.

\section{CONCLUSION}

From the forgoing discussion, one can conclude that prolonged immobilization stress has deleterious effects on the suprarenal cortex and vitamin E has an ameliorative effect that may be mediated through antioxidant effect and stimulation of tissue regeneration by endogenous stem cells.

\section{ACKNOWLEDGMENT}

The authors thank Dr. Basma Hamdy Amin researcher of microbiology at the Regional Center for Mycology and Biotechnology, Al Azhar University for her help during EM preparation.

\section{CONFLICT OF INTEREST}

There are no conflicts of interest.

\section{REFERENCES}

1. Grossman S. Stress and adaptation. In: Grossman SC, Porth CM. Editors, Porth's Pathophysiology Concepts of Altered Health States, $9^{\text {th }}$ edition, ch 9 Wolters Kluwer Health, Lippincott Williams and Wilkins, Philadelphia, USA 2014; 202 - 215.

2. Barrett KE, Barman SM, Boitano S, Brooks HL. Ganong's Review of Medical Physiology, $25^{\text {th }}$ edition, LANGE, McGraw-Hill Education, New York, Chicago, San Francisco, Athens, London 2016; P. 364.

3. Widmaier EP, Raff H, Strang KT. Vander's Human Physiology the Mechanisms of Body Function, $13^{\text {th }}$ edition, McGraw-Hill, New York, Chicago, San Francisco, Athens, London 2014; P. 246.

4. Iwa M, Nakade Y, Pappas TN, Takahshi T. Electro-acupuncture improves restraint stress-induced delay of gastric emptying via central glutaminergic pathways in conscious rats. Neurosci Lett 2006; 399 (1 -2): 6 - 10.

5. Kulkarni MP, Juvekar AR. Attenuation of acute and chronic restraint stress- induced perturbations in experimental animals by Nelumbo nucifera Gaertn. Ind J Pharm Sci 2008; 70 (30): 327 - 332.

6. El-Desouki NI, El-Refaiy AI, Abou-Zaid DFA, Abdel - Kader AA. Histological, histochemical, and immunohistochemical studies of the cardiac muscle of the albino rat under immobilization stress and the curative role of diazepam. Egypt $\mathbf{J}$ Exp Biol (Zool) 2012; 8(2): 273 - 285.

7. Soliman AA. Effect of stress on the mammary gland of lactating albino rat: a light and electron microscopic study. Egypt $\mathrm{J}$ Histol 2006; 29(2): 259 - 268. 
8. El-Derieny EA, Mousa AM. Histological study on the effect of stress on the colonic mucosa of adult male albino rat and possible role of mast cells. Egypt J Histol 2006; 29(2): 315 - 326.

9. Gabry MS, El-Desouki NI, El-Refaiy AI, Ibrahim MA, Mohamed HN. Histological study on the stomach of immobilized-stressed albino rat and the curative role of diazepam. Egypt J Exp Biol (Zool) 2011; 7(2): 153 - 161 .

10. El-Refaiy AI. Histological and histochemical studies on the testes of albino rat under immobilization stress and the possible curative role of diazepam. J Egypt Ger Soc Zool 2010; 60(C): 1 - 22.

11. Mazroa SA, Asker SA. Ultrastructural changes in zona fasciculata cells of suprarenal cortex in adult male albino rats after short exposure to high ambient temperature and the effect of fish oil administration. Egypt J Histol 2010; 33(1): $23-31$.

12. Patra RC, Amiya RK, Swarup D. Oxidative stress in lead and cadmium toxicity and its amelioration. Vet Med Int 2011; 3:18 - 27.

13. Hoogesteijn AL, Raphael BL, Calle P. Oral treatment of avian lead intoxication with meso-2, 3-dimercaptosuccinic acid. J Zoo Wildlife Med 2003; 34(1): 82 - 87 .

14. Humayun Y, Aslam A, Azeem T, Abid SA, Shah MA, Munir MT, Umar S. Toxic effects of lead on biochemical and histological features and their amelioration by vitamin $\mathrm{E}$ in Japanese quails (Coturnix coturnix Japonica) J Avian Res 2015; 1(1):4 - 9

15. Iranpour FG, Kheiri S. Coadministration of calcium chloride with lead acetate can improve motility of cauda epididymal spermatozoa in Swiss white mice. Int J Reprod BioMed 2016; 14(2): 141 - 144.

16. Bancroft JD, Layton C. The hematoxylin and eosin, connective and mesenchymal tissues with their stains. In: Suvarna SK, Layton C and Bancroft JD, editors. Bancroft's Theory and Practice of Histological Techniques. $7^{\text {th }}$ edition, ch 10 and 11, Churchill Livingstone, Philadelphia, $2013 ; 173-212$

17. Steinert AF, Kunz M, Prager P, Göbel S, KleinHitpass L, Ebert R, Nöth U, Jakob F, Gohlke F. Characterization of bursa subacromialis-derived mesenchymal stem cells. Stem Cell Research and
Therapy 2015; 6: $114-127$.

18. Woods AE, Stirling JW. Transmission electron microscopy applications. In: Suvarna SK, Layton C, Bancroft JD, editors. Theory and Practical Histological Techniques. $7^{\text {th }}$ edition, ch 22, Churchill Livingstone, Philadelphia 2013; 493 - 538.

19. Emsley R, Dunn G and White I. Mediation and moderation of treatment effects in randomized controlled trials of complex interventions. Stat Methods Med Res 2010;19 (3): 237- 270.

20. Clayton MF, McCance KL. Stress and disease. In: McCance KL, Huether SE, Brashers VL, Rote NS. Editors, Pathophysiology the Biologic Basis for Disease in Adults and Children, $7^{\text {th }}$ edition, ch. 11 , Elsevier, USA, Canada 2014; 338 - 360.

21. Liu Q, Si T, Xu X, Liang F, Wang L, Pan S. Electromagnetic radiation at $900 \mathrm{MHz}$ induces sperm apoptosis through bcl-2, bax and caspase-3 signaling pathways in rats. Reproductive Health, 2015;12: $65-73$.

22. Paulsen DF. Histology and Cell Biology, Examination and Board Review. $5^{\text {th }}$ edition, McGraw Hill Education, New York, Chicago, San Francisco, Lisbon, Landon, 2010; 307 - 308.

23. Hall JE. Guyton and Hall Textbook of Medical Physiology, 13th edition, ch. 78, Elsevier, Philadelphia 2016; 976 - 977.

24. Cigánková V, Zibrín M, Holovská K. Effect of long - term experimental hypodynamy on the adrenal glands of japanese quails: an ultrastructural study. Bull Vet Inst Pulawy 2005; 49, 449 - 453.

25. Koldysheva E, Lushnikova EL. Ultrastructural reorganization of rat adrenal cortex after whole body hyperthermia. Bull Exp Biol Med 2008;145(5):650 - 655 .

26. Pawlina W. Histology a Text and Atlas with Correlated Cell and Molecular Biology, $7^{\text {th }}$ ed., ch. 9, Wolters Kluwer, Philadelphia, Baltimore, New York, London 2016; 254 - 269.

27. Abd El-Gawad FA, Zaki SM, El-Shaarawy EA, Radwan RA, Aboul-Hoda BE. Histological and histomorphometric reorganization of the adrenal cortex of adolescent male albino rat following exposure to stress. Med J Cairo Univ 2016; 84 (1): $1107-1112$

28. Gilissen EP, Bobrovski LS. Distinct types of 
lipofuscin pigment in the hippocampus and cerebellum of aged cheirogaleid primates. The Anatomical Record 2013; 296:1895 - 1906.

29. Ganesan B, Anandan R, Lakshmanan PT. Studies on the protective effects of betaine against oxidative damage during experimentally-induced restraint stress in Wistar albino rats. Cell Stress Chaperon 2011; 16(6): 641 - 652.

30. Zidan RA and Elnegris HM. A histological study on the effect of noise on the adrenal cortex of adult male guinea pigs and the possible role of combined vitamins (A, C, and E) supplementation. Egypt J Histol 2013; 36:857 - 868 .

31. El-Derieny EA, Mousa AM. Histological study on the effect of stress on the colonic mucosa of adult male albino rat and possible role of mast cells. Egypt J Histol 2006; 29(2): 315 - 326.

32. El-Desouki NI, El-Refaiy AI, Abdel-Azeem H, ElBaely MA. Histological and ultrasructural studies of the effect of immobilization stress on the adrenal cortex of albino rat and the ameliorative role of diazepam. J Egypt Ger Soc Zool 2011; 62: $25-45$.

33. Edrees ZAA, Zickri MB, El-Sherif HA, Mahmoud AH. Histological study on the effect of stem cells, alpha- tocopherol and gene transfected stem cells in adriamycin induced cardiomyopathy of rat. MSC Thesis, 2017, Faculty of Medicine, Cairo University.

34. Sweetman SC. Vitamin E substances, In: Martindale, The Complete Drug Reference. $36^{\text {th }}$ ed., Pharmaceutical Press, UK and USA 2009; 1992 - 1995.

35. Mohameda DS, Abol Hagagb KE. Effect of lead acetate on the histological structure of the adrenal cortex of male albino rats and the possible protective role of vitamin E. Egypt J Histol 2011; 34: $496-504$

36. Zhu YJ, Bo YC, Liu XX, Qiu CG. Association of dietary vitamin $\mathrm{E}$ intake with risk of lung cancer: a dose-response meta-analysis. Asia Pac J Clin Nutr 2017; 26 (2):271 - 277.

37. Pihlajoki M, Dörner J, Cochran RS, Heikinheimo M, Wilson DB. Adrenocortical zonation, renewal, and remodeling. frontiers in Endocrinology 2015; 6 (27) : 1 - 14.

38. Steenblock C, Rubin de Celis MF, AndroutsellisTheotokis A, Sue M, Delgadillo Silva LF, Eisenhofer G, Andoniadou CL, Bornstein SR. Adrenal cortical and chromaffin stem cells: Is there a common progeny related to stress adaptation? Mol Cell Endocrinol 2017; 5 (441):156 - 163.

39. Gesi M, Fornai F, Lenzi P, Natale G, Soldani P and Paparelli A. Time-dependent changes in adrenal cortex ultrastructure and corticosterone levels after noise exposure in male rats. Eur J Morphol 2001; 39 (3): 129 - 135.

40. Armario A, Escorihuela RM, Nadal R. Longterm neuroendocrine and behavioural effects of a single exposure to stress in adult animals. Neurosci Biobehav Rev 2008; 32(6): 1121 - 1135. 
الملخص العربى

دراسة بالميكروسكوب الضوئي والإكتروني علي التأثير الإجهادى لعدم الحركة على قشرة الغدة

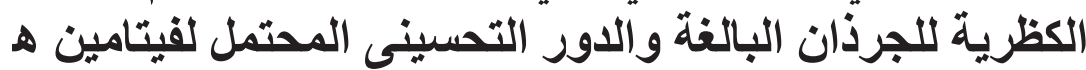

\section{زينب محمد الطيب1 ـ ميسرة محمود سالم22}

\section{1قسم الأنسجة وبيولوجيا الخلية كلية الطب - جامعة حلوان

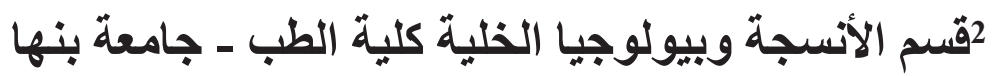

المقدمة: المجتمع الحاضرملىى بالإجهاد، وإجهاد عدم الحركة هو نموذج مستخدم في حيو انات التجارب لدر اسة تأثثير الإجهاد،

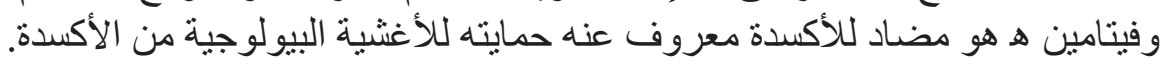

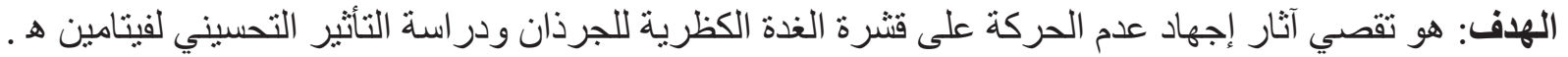

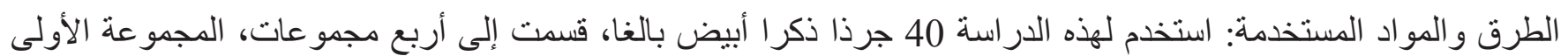

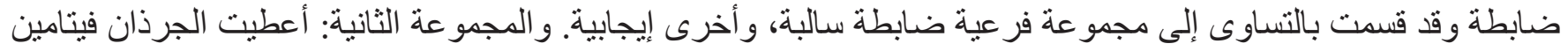

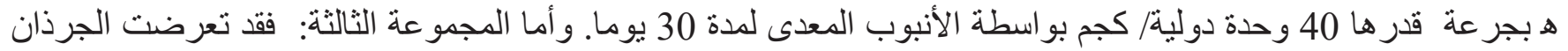

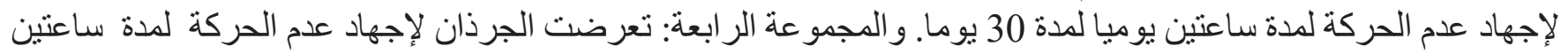

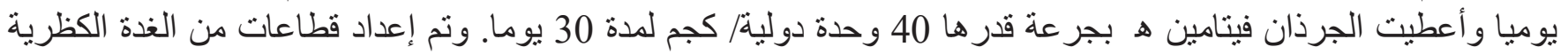
للفحص النسيجى.

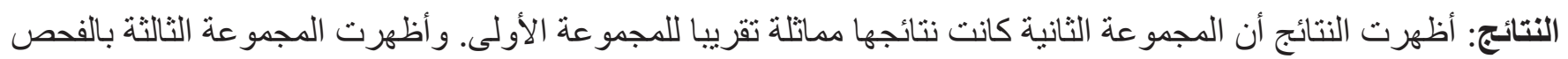

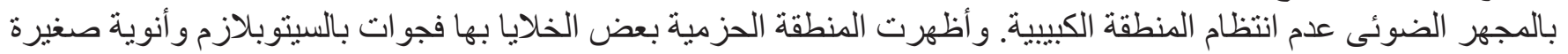

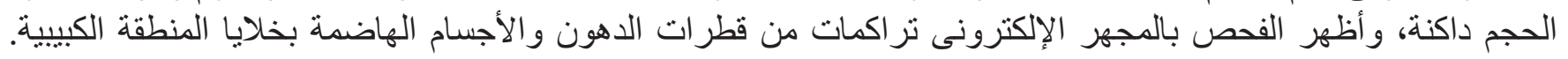

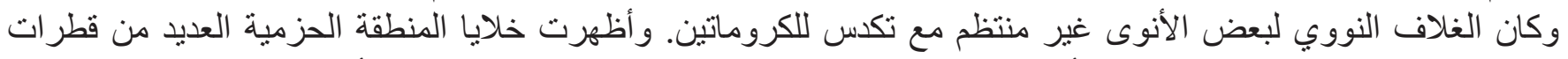

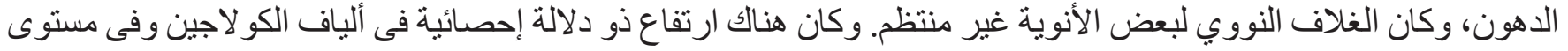

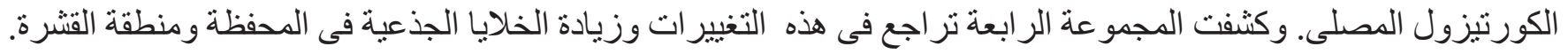
الاستنتاج: إجهاد عدم الحركة أدى إلى تغيير ات ضارة بقتشرية الغدة الكظرية وفيتامين هـ له تأثير تحسيني. 